\title{
Neonatal Edema, AE
}

National Cancer Institute

\section{Source}

National Cancer Institute. Neonatal Edema, AE. NCI Thesaurus. Code C154931.

An adverse event in a newborn characterized by accumulation of an excessive amount of fluid in cells or intercellular tissues. 